\title{
DELAY IN ACTING ON AN APPLICATION FOR INSURANCE
}

\author{
WIIIIAM I. PROSSER*
}

$I^{\prime}$ N THESE days it is a courageous man who takes up the cudgels on behalf of an insurance company, and against the widow and the orphan. The problem of the liability of an insurer who fails to accept or to reject an application for insurance within a reasonable time after receipt by its agent, already has been considered at length in a number of excellent articles. ${ }^{\text {I }}$ Until five years ago, it seemed beyond dispute that the law was moving rapidly in the direction of liability, ${ }^{2}$ and that liability might be justified upon any one of half a dozen highly ingenious theories. ${ }^{3}$ But a series of recent decisions, ${ }^{4}$ some of them very emphatic, if not force-

* Professor of Law, University of Minnesota Law School.

I Funk, The Duty of an Insurer to Act Promptly on Applications, 75 Univ. Pa. L. Rev. 207 (1927); Parkhill, Effect of Delay in Acting upon an Application for Insurance, 7 Fla. Bar Assn. J. 219 (I934); Jones, Tort or No Tort, 56 Chi. Leg. N. 366, 2 Proceedings Assn. of Life Ins. Counsel 389 (I924); Wells, Is a Life Insurance Company Liable in Tort?, 2 Miss. L. J. 293 (1930); Vance, Handbook of the Law of Insurance \$ 64, pp. I88-I94 (2d ed. I930); see notes in 40 Yale L. J. I2I (r930); 32 Mich. L. Rev. 395 (r934); 6 Rocky Mt. L. Rev. 224 (r934); I3 B. U. L. Rev. 734 (1933); 9 Wis. L. Rev. 183 (1934); ro Wis. L. Rev. 289 (1935); I5 Minn. L. Rev. 833 (r93I).

2 Wilkin v. Capital Fire Ins. Co., 99 Neb. 828 , I57 N. W. IO2I (rgr6); Wallace v. Hartford Fire Ins. Co., $3^{I}$ Idaho $48 \mathrm{r}$, I74 Pac. I009 (Ig18); Security Ins. Co. v. Cameron, 85 Okla. I7I, 205 Pac. I5I (1922), 27 A.L.R. 444; Fox v. Volunteer State Life Ins. Co., I85 N.C. I2I, II6 S.E. 266 (1923); De Ford v. New York Life Ins. Co., 75 Colo. I46, 224 Pac. I049 (1924); Dyer v. Missouri State Life Ins. Co., I32 Wash. 378, 232 Pac. 346 (I925); Lewis v. Brotherhood of Locomotive Firemen and Enginemen, 220 Ala. 270, I24 So. 889 (I929); Kukuska v. Home Mut. Hail-Tornado Ins. Co., 204 Wis. 166,235 N.W. 403 (193I); see Behnke v. Standard Acc. Ins. Co., 2 F. (2d) 696 (C.C.A. 7th I930).

3 Funk, The Duty of an Insurer to Act Promptly on Applications, 75 Univ. Pa. L. Rev. 207 (1927); see note in 40 Yale L. J. I2I (I930).

4 Miller v. Illinois Life Ins. Co., 255 Ill. App. 586 (r930); Thornton v. National Council Junior Order United American Mechanics, IIo W.Va. 412, I58 S.E. $5^{\circ} 7$ (I93I); Munger v. Equitable Life Assur. Soc., 2 F. Supp. 9I4 (D.C. Mo. 1933); Swentusky v. Prudential Ins. Co., I16 Conn. 526, I65 Atl. 686 (1933); Schliep v. Commercial Cas. Ins. Co., rgr Minn. 479, 254 N.W. 618 (I934); American Life Ins. Co. v. Nabors, 76 S.W. (2d) 497 (Tex. Comm. App. r934).

In addition there may be listed the cases of Metropolitan Life Ins. Co. v. Brady, 95 Ind. App. 564, r74 N.E. 99 (I932); Moon v. Central States Fire Ins. Co., 138 Kan. 83, 23 P. (2d) 444 (1933); and Wallace v. Metropolitan Life Ins. Co., 212 Wis. 346, 248 N.W. 435 (I933), which seem to be retreating from the view of liability previously taken. Also three cases in which the court, with an excellent opportunity to approve a theory of liability, avoided the issue, and 
ful, in their language, appear to have altered very abruptly the trend of the cases. These decisions suggest a new examination of the question, with the possibility of a different conclusion.

The more or less standardized procedure by which contracts of insurance are made is too familiar to require description. ${ }^{5}$ The applicant for insurance is induced, usually by a soliciting agent of the company, to sign a formal document, designated an "application," which takes the form of an offer looking toward a contract. This application is filled in on a printed form provided by the company, and drawn by its attorneys, and the applicant usually is given no opportunity to suggest or change any of its terms. The agent who takes the application has no authority to conclude a contract, ${ }^{6}$ and his function is merely to transmit the application, together with any premium paid in advance, to the home office of the company for examination by the proper officials. If the risk is approved, a policy of insurance is prepared and executed, which then is forwarded to the agent for delivery to the applicant. At some point after such approval, the contract becomes complete; but not before. The application is quite clearly nothing more than an offer, which requires acceptance by the home office before any insurance is to take effect, and it is so understood by the applicant. Most companies ${ }^{7}$ now protect themselves

disposed of the case on other grounds. Raymond v. National Life Ins. Co., 40 Wyo. $x, 273$ Pac. 667 (rg29) (cf. Dunne v. Western National life Ins. Co., 35 Wyo. 59, 246 Pac. 246 (Ig26)); Veser v. Guardian Life Ins. Co., 44 Ohio App. 293 , I85 N.E. 565 (r932); Weaver v. West Coast Life Ins. Co., 42 P. (2d) 729 (Mont. I935).

s See Patterson, The Delivery of a Life Insurance Policy, 33 Harv. L. Rev. I98 (Igrg);

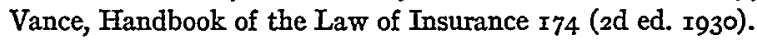

${ }^{6}$ If the agent has such authority and concludes the contract, the insurer of course is bound, and the problem involved here does not arise. Fire insurance agents are given the power to accept the risk more frequently than life insurance agents, and the courts occasionally have taken notice of this fact. See Neuberger v. Aid Assn. for Lutherans, 207 Wis. I33, 240 N.W. 885 (I932); Hertz v. Security Mut. Ins. Co., I3I Minn. I47, I54 N.W. 745 (rgr5). In Eastern Shore of Virginia Fire Ins. Co. v. Kellam, I59 Va. 93, I65 S.E. 637 (I932), it was held that the apparent authority of even a general fire insurance agent to make an oral contract was limited to the time reasonably necessary to issue and deliver a written policy, plus a reasonable time to cover delays and a short period of grace.

7 In rgo5 L. G. Fouse, president of a life insurance company, declared that all of fifty-one representative companies inserted provisions that the policies should not take effect until they were delivered during the lifetime and good health of the applicant, with actual payment of the first premium. 26 Annals Acad. Pol. and Soc. Sci. 209, 220 (xgog), Yale Readings in Insurance, 207, 219 (rgog). In 1921 John A. Coke, Jr., attorney for the Life Insurance Co. of Virginia, reported that out of 125 applications and policies examined, eighty-seven required both de- 
by inserting in the application express provisions that there shall be no insurance until the formal policy has been delivered to the applicant, and the first premium paid. ${ }^{8}$

The company of course is entitled to a reasonable time to pass on the application.9 After such a reasonable time has elapsed, common courtesy and a decent consideration for the applicant, to say nothing of orderly business practice, require that the company send notice that the application is rejected, or that more time is required. If the company, or its agent, takes no action, the applicant continues to be deprived of the use of any money paid in advance; but more important than this is the fact that he is not insured. If a loss occurs, there is no policy to cover it; and there is a possibility that if he had been notified, he might have obtained protection elsewhere. The apparent hardship upon the applicant, especially where it is clear that he was an acceptable risk and the company had no reason for rejecting him, calls for sympathy, and has led to the development of a great deal of hard case law.

The doctrine of liability of the insurance company for unreasonable delay is of comparatively recent origin. There were dicta in a few early cases ${ }^{10}$ indicating that there might be recovery on the theory of negligence, and a decision of the supreme court of Hawaii, ${ }^{1 x}$ which attracted little attention, first confirmed the suggestion; but it was not until I9I2 that Kansas, ${ }^{12}$ followed almost at once by Iowa, ${ }^{\mathrm{I3}}$ really set the tort theory in motion. Liability has been supported, upon one basis or another, in

livery in good health and payment of the first premium as conditions precedent to the commencement of the risk. The Commencement of the Risk in the Case of a Life Insurance Policy, I Proceedings of Assn. Life Ins. Counsel, no. 5 I (I92I).

${ }^{8}$ The following provision is typical: "The company shall incur no liability under this application, until it shall have been received and approved at the home office of the said company, the policy issued and delivered to me during my life time and good health, and the first premium paid and accepted by the company or its authorized agent."

9 This is recognized by courts holding that unreasonable delay will impose liability. Meyer v. Central States Life Ins. Co., I03 Neb. 640, I 73 N.W. 578 (1919); De Ford v. New York Life Ins. Co., 8I Colo. 5I8, 256 Pac. 317 (1927); Evans v. International Life Ins. Co., 122 Kan. 264, 252 Pac. 266 (I927); Behnke v. Standard Acc. Ins. Co., 4I F. (2d) 696 (C.C.A. 7th 1930); Winn v. John Hancock Mut. Life Ins. Co., 216 Iowa I249, 250 N.W. 459 (I933).

so Perkins v. Washington Ins. Co., 4 Cow. (N.Y.) 645 (1825); Walker v. Farmers' Ins. Co., 51 Iowa 679, 2 N.W. 583 (1879); Trask v. German Ins. Co., 53 Mo. App. 625 (1893); Stewart v. Helvetia Swiss Fire Ins. Co., ro2 Cal. 218, 36 Pac. 410 (1894).

Ix Carter v. Manhattan Life Ins. Co., Ir Hawaii 69 ( $(8997)$.

rz Boyer v. State Farmers' Mut. Hail Ins. Co., 86 Kan. 443, I2I Pac. 329 (x9г2), 40 L.R.A. (N.S.) 164, Ann. Cas. I915A 67I.

${ }^{2}$ Duffie v. Bankers' Life Assn., I60 Iowa I9, I39 N.W. I087 (I913), 46 L.R.A. (N.S.) 25. 
Alabama, ${ }^{14}$ California, ${ }^{15}$ Colorado, ${ }^{16}$ Hawaii, ${ }^{17}$ Idaho, ${ }^{18}$ Iowa, ${ }^{19}$ Kansas, ${ }^{20}$ Kentucky, ${ }^{21}$ Michigan, ${ }^{22}$ Nebraska, ${ }^{23}$ North Carolina, ${ }^{24}$ North Dakota, ${ }^{25}$ Oklahoma, ${ }^{26}$ Tennessee, ${ }^{27}$ Washington, ${ }^{28}$ Wisconsin, ${ }^{29}$ and a federal circuit (I929).

${ }^{24}$ Lewis v. Brotherhood of Locomotive Firemen and Enginemen, 220 Ala. 270, I24 So. 889

Is Stark v. Pioneer Cas. Co., 34 P. (2d) 73 I (Cal. App. 1934).

${ }^{6}$ De Ford v. New York Life Ins. Co., 75 Colo. 146, 224 Pac. xo49 (rg24). Upon a second appeal, it was held that the delay was not unreasonable. De Ford v. New York Life Ins. Co., 8I Colo. 5I8, 256 Pac. 3 I7 (rg27).

${ }^{27}$ Carter v. Manhattan Life Ins. Co., Ix Hawaii 69 (1897).

18 Wallace v. Hartford Fire Ins. Co., 3r Idaho 48x, x74 Pac. Ioog (Igr8).

19 Duffie v. Bankers' Life Assn., I60 Iowa I9, 139 N.W. 1087 (I9r3), 46 L.R.A. (N.S.) 25; Johnson v. Farmers' Ins. Co., I84 Iowa 630 , x68 N.W. 264 (Igr8); Mortimer v. Farmers' Mut. Fire and Lightning Ins. Assn., 2 I 7 Iowa $\times 246,249$ N.W. 405 (I933). See also Winn v. John Hancock Mut. Life Ins. Co., 2 I6 Iowa I249, 250 N.W. 459 (I933).

${ }^{20}$ Preferred Acc. Ins. Co. v. Stone, 6r Kan. 48, 58 Pac. 986 (x899) (contract theory); Boyer v. State Farmers' Mut. Hail Ins. Co., 86 Kan. 442, I2r Pac. 329 (rgr2), 40 L.R.A. (N.S.) I64, Ann. Cas. I9I5A 67I; see Evans v. International Life Ins. Co., I22 Kan. 264, 252 Pac. 266 (I927). But cf. Moon v. Central States Fire Ins. Co., I38 Kan. 83, 23 P. (2d) 444 (I933).

${ }^{21}$ Northwestern Mut. Life Ins. Co. v. Neafus, I45 Ky. 563, I40 S.W. ro26 (I9II) (dichum); see also Continental Ins. Co. v. Haynes, ro Ky. L. Rep. 276 (1888) and Halle v. New York Life Ins. Co., 22 Ky. L. Rep. 740, 58 S.W. 822 (I900), both holding that under the terms of the application the contract of insurance was effective at once, subject to the right to reject.

${ }^{22}$ Robinson v. United States Ben. Soc., ${ }_{32}$ Mich. 695,94 N.W. eII, ro2 Am. St. Rep. $43^{6}$ ( $x 0^{\circ} 3$ ) (contract theory).

${ }^{23}$ In Wilken v. Capital Fire Ins. Co., 99 Neb. 828, I57 N.W. ro2I (x9I6), the court found liability on the theory of negligence of the agent, chargeable to the company. In Meyer $v$. Central States Life Ins. Co., I03 Neb. 640, $x_{73}$ N.W. 578 ( $(9 \mathrm{~g}$ (9), a dictum rejected the idea of tort liability, and a concurring opinion opposed it vigorously. Later decisions indicate that the earlier case will be followed. See Handlier v. Knights of Columbus, I06 Neb. 267, 183 N.W. 300 (I92I); Page v. National Automobile Ins. Co., rog Neb. I27, Igo N.W. 213 (I922); Strand v.

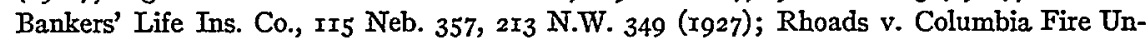
derwriters' Agency, 260 N.W. I74 (Neb. I935).

${ }^{24}$ Fox v. Volunteer State Life Ins. Co., I85 N.C. I2I, II6 S.E. 266 (I923).

${ }^{25}$ An unreported decision of a lower court, tacitly approved in In re Coughlin's Estate, 53 N.D. $x 88,205$ N.W. I4 (I925). See also Stearns v. Merchants' Life and Cas. Co., 38 N.D. 524, I6 5 N.W. 568 (19r7).

${ }^{26}$ Security Ins. Co. v. Cameron, 85 Okla. x7I, 205 Pac. I5I (r922), 27 A.L.R. 444; Columbian Nat. Life Ins. Co. v. Lemmons, 96 Okla. 228, 222 Pac. 255 (r923); Childers v. New York Life Ins. Co., Ir7 Okla. 7, 245 Pac. 59 (I925); Brown v. Missouri State Life Ins. Co., I24 Okla. I55, 254 Pac. 7 (I927).

${ }_{27}$ Richmond v. Travelers' Ins. Co., $x_{23}$ Tenn. 307, r3o S.W. 790 (r9ro), 30 L.R.A. (N.S.) 954 (dictum that there may be estoppel against the company).

${ }^{28}$ Dyer v. Missouri State Life Ins. Co., 132 Wash. 378, 232 Pac. 346 (x925), Affd. I35 Wash. 693, 236 Pac. 807 (I925).

a9 Kukuska v. Home Mut. Hail-Tornado Ins. Co., 204 Wis. I66, 235 N.W. 403 (I93I). In Wallace v. Metropolitan Life Ins. Co., 212 Wis. 346 , 248 N.W. 435 (r933), the court expressed considerable doubt whether life insurance was subject to the same conclusion, and disposed of the case upon the ground that no damages had been proved. 
court of appeals. ${ }^{30}$ Liability has been rejected definitely in Arkansas, ${ }^{3 x}$ Connecticut, ${ }^{32}$ Illinois, ${ }^{33}$ Minnesota, ${ }^{34}$ Mississippi, ${ }^{35}$ Texas, ${ }^{36}$ West Virginia, ${ }^{37}$ a federal district court of Missouri, ${ }^{38}$ and probably in Indiana; ${ }^{39}$ while Missouri, ${ }^{40}$ Ohio, ${ }^{45}$ Wyoming,,$^{42}$ and Montana ${ }^{43}$ have refused to take any stand.

An examination of the twenty-odd cases sustaining the liability of the insurance company for unreasonable delay immediately reveals the fact that there is more agreement upon the conclusion that the company should pay than upon any process of reasoning to support it, and conveys the impression that "most of them were written with scissors and paste." 44 Many of the theories advanced seem to justify the recent comment of Judge Otis:

At first thought one is almost led to say that these are bricks made without straw, and also without clay, which, moreover, never have been baked. One is inclined to think that the cases .... which were not reasoned (but went on precedent), after all were the best reasoned.45

${ }^{30}$ Behnke v. Standard Acc. Ins. Co., 4I F. (2d) 696 (C.C.A. 7th 1930) (dictum).

${ }^{3 x}$ National Union Fire Ins. Co. v. School District No. 55, 122 Ark. I79, I82 S.W. 547 (rg16), L.R.A. rgr6D 238; Inter-State Business Men's Acc. Assn. v. Nichols, r43 Ark. 369, 220 S.W. 477 (1920).

${ }^{32}$ Swentusky v. Prudential Ins. Co., Ir6 Conn. 526, I65 Atl. 686 (I933).

33 Bradley v. Federal Life Ins. Co., 295 Ill. 38r, I29 N.E. I7r (r920); Miller v. Dlinois Life Ins. Co., 255 Ill. App. 586 (x930).

${ }^{34}$ Schliep v. Commercial Cas. Ins. Co., I9I Minn. 479, 254 N.W. 6I8 (r934); Tjepkes v. State Farmers' Mut. Ins. Co., 259 N.W. 2 (Minn. 1935).

35 Savage v. Prudential Life Ins. Co., 154 Miss. 89, I2r So. 487 (1929).

${ }^{36}$ American Life Ins. Co. v. Nabors, 76 S.W. (2d) 497 (Tex. Comm. App. x934), reversing 48 S.W. (2d) 459 (Tex. Civ. App. 1932). To the contrary is Great Southern Life Ins. Co. v. Dolan, 239 S.W. 236 (Tex. Civ. App. r922) (contract, and estoppel) reversed in 262 S.W. 475 (Tex. Comm. App. 1924), on the ground that there was no contract with the agent.

37 Thornton v. National Council Junior Order United American Mechanics, Iro W.Va. 4r2, I58 S.E. 507 (1931); Chittum v. Commonwealth Life Ins. Co., I77 S.E. 782 (W.Va. I934).

${ }^{38}$ Munger v. Equitable Life Assur. Soc., 2 F. Supp. 914 (D.C. Mo. r933).

39 There is a dictum in Live Stock Ins. Assn. v. Stickler, 64 Ind. App. rgr, II 5 N.E. $69 \mathrm{I}$ (I9I7), that there may be tort liability. But in Metropolitan Life Ins. Co. v. Brady, 95 Ind. App. 564,174 N.E. 99 (1932), the court refused to hold the company liable where no advance premium had been paid, and apparently disapproved liability in any case.

${ }_{40}$ Forck v. Prudential Ins. Co., 66 S.W. (2d) 983 (Mo. App. 1933) (does not disclose the court's position, but if anything favors liability).

${ }_{41}$ Veser v. Guardian Life Ins. Co., 44 Ohio App. 293, 185 N.E. 565 (I932).

${ }_{42}$ Dunne v. Western Nat. Life Ins. Co., 35 Wyo. 59, 246 Pac. 246 (rg26) (no liability in the absence of a premium payment); Raymond v. National Life Ins. Co., 40 Wyo. r, 273 Pac. 667 (I929).

${ }_{43}$ Weaver v. West Coast Life Ins. Co., 42 P. (2d) 729 (Mont. 1935).

${ }_{44}$ Otis, J., in Munger v. Equitable Life Assur. Soc., 2 F. Supp. 914 , 915 (D.C. Mo. I933). ${ }_{45}$ Munger v. Equitable Life Assur. Soc., 2 F. Supp. 914, 9 I7 (D.C. Mo. 1933). 
In the face of a dozen diversified theories, it is difficult to do more than to tabulate the list, with the objections which may be made to each. At the outset we are met with a series of attempts to evolve some principle upon which the insurer may be held to have entered into a contract, even in the absence of any intent to do so.

\section{SILENCE GIVES CONSENT}

The application is an offer looking toward a contract. It may be accepted by an expression of assent on the part of the company. The company has solicited the offer, and so has indicated in advance its willingness to contract if the risk is acceptable. Reasonable men would reject such an offer promptly, if there were no intent to accept it. It is contended therefore that failure to reject within a reasonable time is an acceptance on the part of the company, which completes the contract of insurance. ${ }^{46}$

Such a contention is contrary to well established principles of contract law, ${ }^{47}$ and is repudiated by an overwhelming array of insurance cases..$^{48}$

${ }^{46}$ Preferred Acc. Ins. Co. v. Stone, 6I Kan. 48, 58 Pac. 986 (I899); Robinson v. United States Ben. Soc., I32 Mich. 695, 94 N.W. 21 I (I903), I02 Am. St. Rep. 436; Great Southern Life Ins. Co. v. Dolan, 239 S.W. 236 (Tex. Civ. App. r922), reversed on rehearing 262 S.W. 475 (Tex. Comm. App. r924); Cloyd v. Republic Mut. Fire Ins. Co., 137 Kan. 869, 22 P. (2d) 43 ( (1933).

47 Restatement, Contracts $\S 72$ (I932); I Williston, Contracts $\S 9$ I (I920); I Page, Contracts $\$ \$ 50,160,16 \mathrm{r}$ (I905); Corbin, Offer and Acceptance and Some of the Resulting Legal Relations, 26 Yale L. J. I69 (I9x7); 29 Yale L. J. 44I (I920); 33 Harv. L. Rev. 595 (I920).

${ }^{48}$ Misselhorn v. Mutual Reserve Fund Assn., 30 Fed. 545 (C.C. Mo. I887); Steinle v. New York Life Ins. Co., 8I Fed. 489 (C.C.A. $5^{\text {th }}$ I897); Alabama Gold Life Ins. Co. v. Mayes, 6I Ala. I63 (I878); National Union Fire Ins. Co. v. School District No. 55, I22 Ark. I79, I82 S.W. 547 (rgr6), L.R.A. Igr6D 238; Stewart v. Helvetia Swiss Fire Ins. Co., roz Cal. 218 (I894); Easley v. New Zealand Ins. Co., 5 Idaho 593, 5 r Pac. 4I8 (I897); Miller v. Illinois Life Ins. Co., 255 Ill. App. 586 (I930); Live Stock Ins. Assn. v. Stickler, 64 Ind. App. I9I, Ix5 N.E. 69I (Igr7); Walker v. Farmers' Ins. Co., 5 I Iowa 679, 2 N.W. 447 (I879); Trask v. German Ins. Co., 53 Mo. App. 625 (1893); St. Paul Fire \& Marine Ins. Co. v. Kelly, 2 Neb. (Unof.) 720, 89 N.W. 997 (I902); Handlier v. Knights of Columbus, ro6 Neb. 267, I83 N.W. 300 (I92I); More v. New York Bowery Fire Ins. Co., I3o N.Y. 537, 29 N.E. 757 (I892); Ross v. New York Life Ins. Co., r24 N.C. 395, 32 S.E. 733 (x899); Home Forum Benefit Order v. Jones, 5 Okla. 598, 50 Pac. I65 (r897); Dorman v. Connecticut Fire Ins. Co., $4 \mathrm{r}$ Okla. 509, r $_{39}$ Pac. 262 (r914), 5 I L.R.A. (N.S.) 873; Insurance Co. v. Johnson, 23 Pa. 72 (I854); Royal Ins. Co. v. Beatty, Irg Pa. St. 6, I2 Atl. 607 (1888); Brink v. Merchants' and Farmers' United Mut. Ins. Co., x7 S.D. 235, 95 N.W. 929 (rgo3); McLendon v. Woodmen of the World, ro6 Tenn. 695, 64 S.W. $3^{6}$ (Igor); Connecticut Mut. Life Ins. Co. v. Rudolph, 45 Tex. 454 (r876); Haden v. Farmers and Merchants Fire Assn., 80 Va. 683 (1885); Northern Neck Mut. Fire Assn. v. Turlington, I36 Va. 44, II6 S.E. 363 (I923); Raymond v. National Life Ins. Co., 40 Wyo. I, 273 Pac. 667 (r929).

In addition, there are dicia in Kohen v. Mutual Reserve Fund Assn., 28 Fed. 705 (C.C. Mo. 1886); Equitable Life Ass. Soc. v. McElroy, 83 Fed. 63 I (C.C.A. 8th r897); Heiman v. Phoenix Mut. Life Ins. Co., $x 7$ Minn. I53 (I87I); Haskin v. Agricultural Fire Ins. Co., 78 Va. 700 (I894). See also Moon v. Central States Fire Ins. Co., r38 Kan. 83, 23 P. (2d) 444 (r933). 
An offer imposes no duty of action upon the offeree; there is no obligation to accept or to reject it, or to take any notice of it. Silence is not to be construed as acceptance, but rather is taken by reasonable men to indicate that the offer has not been received, that it is still being considered, or that it has been rejected. ${ }^{49}$ When the applicant hears nothing, he is free to make inquiry, or to withdraw the offer and apply elsewhere, but he may not assume acceptance. ${ }^{\circ 0}$ There is nothing about an insurance application to take the case out of ordinary contract rules. ${ }^{5 x}$ If the situation were reversed, and the company were seeking to recover premiums, ${ }^{52}$ or if the offer had been made by the company in the first instance, ${ }^{53}$ silence would not constitute acceptance. It is true that a duty to speak may be imposed by special circumstances, ${ }^{54}$ under which a reasonable man would

49 "A proposal not answered remains a proposal for a reasonable time, and is then regarded as withdrawn. Both parties are interested in its acceptance, and both are expected to attend to it with reasonable diligence." Insurance Co. v. Johnson, 23 Pa. 72 (I854). "Instead of silence being evidence of an agreement to do the thing requested, it is evidence, either that the question was not heard, or that it was not intended to comply with the request. Especially is this the case when, if a compliance was intended, the request would have been followed by an actual doing of the thing requested." Royal Ins. Co. v. Beatty, Irg Pa. St. 6, r2 Atl. 607 (I888).

so "If the appellant was dilatory in acting on the proposal, the deceased could have quickened its diligence by demanding prompt action; or, if not assenting to the delay, he could have retracted his proposal, and reclaimed the money he had advanced, and his note. He had no right, without action on his part, to rely on the supineness of the appellant, no greater than his own, as an acceptance of the proposal." Alabama Gold Life Ins. Co. v. Mayes, 6r Ala. r63 (1878). See also Royal Ins. Co. v. Beatty, IIg Pa. St. 6, I2 Atl. 607 (I888); Winchell v. Iowa State Life Ins. Co., I03 Iowa 189,72 N.W. 503 (1897); Savage v. Prudential Life Ins. Co., I54 Miss. 89, I21 So. 487 (r929); Lamb v. Mechanics' Ins. Co., I22 Kan. 352, 252 Pac. 213 (Ig27); Munger v. Equitable Life Assur. Soc., 2 F. Supp. 9r4 (D.C. Mo. I933).

sI "It is of course true that failure to act upon it may, in such a case as this, cause loss to the applicant or to those to be named as beneficiaries in the policy, against which he expected to secure protection. That situation is not, however, peculiar to the insurance law; for example, one may make an offer to buy goods which he needs at a certain price, having reason to believe the price will advance, and may incure loss through the failure of the one to whom it is made to act upon the offer within a reasonable time." Swentusky v. Prudential Ins. Co., ir6 Conn. 526, r65 Atl. 686 (r933).

52 Van Arsdale v. Osborne \& Young, 2I Okla. I5I, 95 Pac. 778 (rgo8); Home Ins. Co. v. Swann, 34 Ga. App. I9, I28 S.E. 70 (I925).

s3 Prescott v. Jones, 69 N.H. 305 (I898); Richmond v. Travelers' Ins. Co., 123 Tenn. 307, I30 S.W. 790 (I9I0), 30 L.R.A. (N.S.) 954; Shakman v. United States Credit System Co., 92 Wis. 366,66 N.W. 528 ( 1896 ), 32 L.R.A. 383, 53 Am. St. Rep. 920; $c f$. New v. Germania Fire Ins. Co., r7 Ind. 33,85 N.E. 703 (Ig08), I3 1 Am. St. Rep. 245; MacKelvie v. Mutual Benefit Life Ins. Co., 287 Fed. 660 (C.C.A. $2 d$ I923).

54 Restatement, Contracts, $\$ 72$, p. 78 (I932), Illustration of Subsection (I,c); $c f$. Lechler v. Montana Life Ins. Co., 48 N.D. 644 , I86 N.W. 27 I (rg2r), 23 A.L.R. II93, involving a renewal policy, where relations between the parties had been such as to justify the offeror in expecting a reply. 
not remain silent, ${ }^{55}$ and there are cases ${ }^{56}$ which have not gone unchallenged, ${ }^{57}$ holding that where a salesman is given an order for so many boxes of shoes, pickles or dried fish, his principal must act upon the offer within a reasonable time, $5^{8}$ or he will be deemed to have accepted it. But an application for insurance usually contains an express provision ${ }^{59}$ that the company shall incur no liability in connection with the application until a formal policy has been issued and delivered; and no case has been found, outside of the field of insurance law, holding silence to be acceptance, in the face of such an express statement.

\section{RETENTION OF ADVANCE PAYMENTS AS ACCEPTANCE}

Where the applicant paýs all or part of the first premium to the agent at the time of the application, the payment is of course conditional, and is to be returned to the applicant if his offer is not accepted. Sometimes this is expressly agreed, ${ }^{60}$ but in all cases it is clearly understood. The company has no right to retain the payment, unless it accepts the application; and when it does retain it beyond a reasonable time, it is argued that this is acceptance. ${ }^{6 r}$

5s Corbin, Offer and Acceptance and Some of the Resulting Legal Relations, 26 Yale L. J. I69, 200 (I9I7).

${ }^{56}$ Bluegrass Cordage Co. v. Luthy \& Co., 98 Ky. 583, 33 S.W. 835 (I896); Cole-McIntyreNorfleet Co. v. Holloway, I4I Tenn. 679, 214 S.W. 8I7 (r9I9), 7 A.L.R. I683; Peterson v. Graham-Brown Shoe Co., 2xo S.W. 737 (Tex. Civ. App. Igrg); Hendrickson v. International Harvester Co., roo Vt. r6r, I35 Atl. 702 (r926); see 8 Minn. L. Rev. 250 (I924).

57 Gould v. Cates Chair Co., $x_{47}$ Ala. 629, 4I So. 675 (xgo6); Metzler v. Harry Kaufman Co., 32 App. D. C. 434 (Ig09); Senner \& Kaplan Co. v. Gera Mills, r85 App. Div. 562, I73 N.Y.S. 265 (I9I8). See also Raysor v. Berkeley Co. Ry. \& Lumber Co., 26 S.C. 6ro, 2 S.E. Ir9 (I887).

$5^{8}$ "And thus it is that it is frequently said that one is ordinarily under no obligation to do or say anything concerning a proposition which he does not choose to accept, yet we think that when one sends out an agent to take such orders subject to his (the principal's) approval, fair dealing and the exigencies of modern business require us to hold that he shall signify to the customer within a reasonable time from the receipt of the order his rejection of it, or suffer the consequences of having his silence operate as an approval." Hendrickson v. International Harvester Co., I00 Vt. I6I, I35 Atl. 702 (I926).

59 See note 8, supra.

${ }^{60}$ See Childers v. New York Life Ins. Co., I 7 Okla. 7, 245 Pac. 59 (I925); Cloyd v. Republic Mut. Fire Ins. Co., r37 Kan. 869, 22 P. (2d) 43 I (I933).

6x Preferred Acc. Ins. Co. v. Stone, 6r Kan. 48, 58 Pac. 986 (r899); Robinson v. United States Ben. Soc., I32 Mich. 695, 94 N.W. 21x (r903), ro2 Am. St. Rep. 436; Great Southern Life Ins. Co. v. Dolan, 239 S.W. 236 (Tex. Civ. App. I922), reversed on rehearing 262 S.W. 475 (Tex. Comm. App. r924). In Cloyd v. Republic Mut. Fire Ins. Co., I37 Kan. 869, 22 P. (2d) 43 I (I933) and Stearns v. Merchants' Life \& Cas. Co., 38 N.D. 524, I65 N.W. 568 (I9I7), acceptance was found upon the basis of express agreements that the payment would be returned if no policy was issued. See also Restatement, Contracts, $\$ 72(2)$, p. 77 (1932). 
The difficulty with this argument is that the company has not "retained" the money; it has merely failed to return it. The applicant might have it back at any time upon demand.62 The money was deposited with the company's agent for a special purpose, pending a decision on the application. Until there has been a rejection, or the applicant has demanded the money, the company's possession is still entirely consistent with the original purpose, since there still may be acceptance. Under an application expressly providing that there shall be no insurance until the issuance of a policy, it is difficult to see how failure to return a payment can amount to acceptance; and until there has been a demand for its return, it is doubtful whether there would be even a conversion of the money.

\section{ESTOPPEL}

This convenient catch-all has received occasional mention, ${ }^{63}$ apparently upon the imperfectly conceived notion that the conduct of the company has in some way misled the applicant into foregoing the opportunity to obtain other insurance. Estoppel, properly so called, must be based upon a representation of fact, in reliance upon which the applicant must have been misled to his detriment. ${ }^{6}$ The company has made no representation of fact, and not even a promise; and unless we are to say that silence may be relied upon as acceptance, ${ }^{65}$ the applicant could scarcely. have been misled as to the fact that he had no insurance, and the necessity of applying elsewhere. ${ }^{66}$

\section{DATING BACK THE POLICY}

Many insurance companies have followed the pernicious practice of giving the policy, when issued, the date of the original application, and

${ }^{62}$ Cf. Stilwell v. Covenant Mut. Life Ins. Co., 83 Mo. App. $21_{5}$ (xgoo).

${ }_{63}$ Preferred Acc. Ins. Co. v. Stone, 6I Kan. 48, 58 Pac. 986 ( 1899 ); Robinson v. United States Ben. Soc., I32 Mich. 695, 94 N.W. 2 II (I903), IO2 Am. St. Rep. 436; Great Southern Ins. Co. v. Dolan, 239 S.W. 236 (Tex. Civ. App. I922), reversed on rehearing 262 S.W. 475 (Tex. Comm. App. I924); see Richmond v. Travelers' Ins. Co., I23 Tenn. 307, I30 S.W. 790 (rgro), 30 L.R.A. (N.S.) 954; cf. Gonsoulin v. Equitable Life Assur. Soc., I52 La. 865, 94 So. 424 (rg22).

${ }^{64}$ Vance, Handbook of the Law of Insurance, pp. 5I4-5I6 (2d ed. 1930); 33 Harv. L. Rev. 595 (1920).

65 See notes 49 and 5o, supra, and text.

${ }^{66}$ The estoppel theory is rejected in More v. New York Bowery Fire Ins. Co., I3o N.Y. 537, 29 N.E. 757 (r892); Winchell v. Iowa State Ins. Co., I03 Iowa 189,72 N.W. 503 (I897); Connecticut Mut. Life Ins. Co. v. Rudolph, 45 Tex. 454 (I876); cf. Prescott v. Jones, 69 N.H. 305 (1898); see Coker v. Atlas Acc. Ins. Co., 3I S.W. 703 (Tex. Civ. App. 1895). See also Reed v. Prudential Ins. Co., 73 S.W. (2d) I027 (Mo. App. r934). For the most part it has been ignored by the courts. The cases cited in note 48 would appear, by implication at least, to reject it. 
requiring premiums to be paid on anniversaries of that date. ${ }^{67}$ This practice leads to a choice of two very unsatisfactory legal results. If it be held that the insurance is not effective until the policy is issued, the applicant will have paid a premium covering the interval following the application, during which he will not have been covered by insurance. If, on the other hand, it is held that the insurance is effective as of the date of application, it is possible that the applicant may receive protection for which he pays no premium, since the application may be rejected, or withdrawn before acceptance. Two reasonable solutions present themselves. If the practice of the company, or anything in the application or the receipt given, has misled the applicant into a belief that he is insured from the earlier date, the agent should be held to have at least apparent authority to make the contract, and the company should be bound without the issue of a policy. ${ }^{68}$ If such authority is clearly negatived, as it would seem to be by an express provision in the application that there shall be no insurance until the policy is delivered, ${ }^{69}$ then the date of the policy should be disregarded, and future premiums held payable at proper intervals after the applicant becomes insured..$^{\circ}$ It has been contended that the practice of dating the policy back imposes on the company a contract obligation to act promptly upon the application..$^{7 x}$ This seems entirely unsound..$^{72}$ If there is any contract at all, it is to insure forthwith. No reasonable interpretation of the conduct of either party could lead to any understanding that the applicant is to pay a premium covering an interval during which there is no insurance, provided that it be limited to the period reasonably necessary for prompt action.

${ }_{67}$ See the annotations in 6 A.L.R. 774 (1920); 32 A.L.R. I253 (I924); also 3 Couch, Cyclopedia of Insurance Law, $\$ 634$.

${ }^{68}$ Koivisto v. Bankers \& Merchants Fire Ins. Co., I48 Minn. 255, I8I N.W. 580 (I92 I); Continental Ins. Co. v. Haynes, xo Ky. L. Rep. 276 (I888); Halle v. New York Life Ins. Co., 22 Ky. L. Rep. 740, 58 S.W. 822 (x900).

69 Olson v. American Central Life Ins. Co., 172 Minn. 5Ir, 216 N.W. 225 (1927).

${ }^{70}$ McMaster v. New York Life Ins. Co., I83 U.S. 25 (rgor); Stramback v. Fidelity Mut. Life Ins. Co., 94 Minn. 28I, IO2 N.W. 73 I (1905); Stinchcombe v. New York Life Ins. Co., 46 Or. 3I6, 80 Pac. 213 (I905); Halsey v. American Central Life Ins. Co., 258 Mo. 659, I67 S.W.

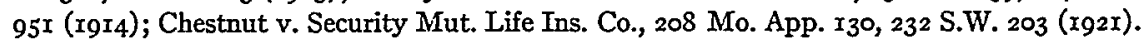

7r De Ford v. New York Life Ins. Co., 75 Colo. I46, 224 Pac. Io49 (I924); Security Ins. Co. v. Cameron, 85 Okla. $x 7$ I, 205 Pac. I5 (Ig22), 27 A.L.R. 444. And see Duffie v. Bankers' Life Assn., 160 Iowa I9, I39 N.W. 1087 (I9I3), 46 L.R.A. (N.S.) 25.

72 See the following cases, where the court refused to find any preliminary agreement, notwithstanding this practice on the part of the company: Alabama Gold Life Ins. Co. v. Mayes, 6I Ala. I63 (I878); Pickett v. German Fire Ins. Co., 39 Kan. 697, I8 Pac. 903 (I888); Steinle v. New York Life Ins. Co., 8I Fed. 489 (C.C.A. 5th I897); Northwestern Mut. Life Ins. Co. v. Neafus, 145 Ky. 563, I40 S.W. 1026 (Igrr); More v. New York Bowery Fire Ins. Co., I30 N.Y. 537, 29 N.E. 757 (1892); Shawnee Mut. Fire Ins. Co. v. McClure, 39 Okla. 535, I35 Pac. II50 (rgr3); Connecticut Mut. Ins. Co. v. Rudolph, 45 Tex. 454 (I876). 


\section{. v. "IMPLIED AGREEMENT" AND "QUAST-CONTRACT"}

A few courts have attempted to spell out a liability based upon an "implied" agreement, made at the time of the application, that the agent will forward it promptly, and the company will act without delay. ${ }^{73}$ The precarious nature of this theory has been recognized by terming the agreement "implied if not legal," 74 and "consensual, and therefore in the nature of a quasi contractual liability." 75 Assuming that such an agreement can be found, and that the agent has authority to make it, ${ }^{76}$ the company would of course be liable for its breach.

It is undisputed that there is a clear moral obligation upon the company to act without unreasonable delay; and it may very well be that there is a vague undefined understanding that it intends and is expected to do so. But a contract implied in fact must rest upon the intent of the parties; it requires an agreement, a meeting of minds, an intent to promise and be bound; ${ }^{77}$ it does not differ from an express contract, except that it is circumstantially proved..$^{78}$ Before the company can be held upon such an agreement, it must be found as a reasonable implication from the circumstances and the conduct of the parties that it intended to bind itself by a promise of prompt action. ${ }^{79}$ In the ordinary case, this is simply contrary to fact. ${ }^{80}$ The form of the transaction indicates no such intent. ${ }^{8 \mathrm{x}}$

${ }^{73}$ Columbian Nat. Life Ins. Co. v. Lemmons, 96 Okla. 228, 222 Pac. 255 (I923); Fox v. Volunteer State Life Ins. Co., I85 N.C. I2x, Ix6 S.E. 266 (I923); De Ford v. New York Life Ins. Co., 75 Colo. 146, 224 Pac. ro49 (I924); Dyer v. Missouri State Life Ins. Co., 132 Wash. 378, 232 Pac. 346 (rg25); Brown v. Missouri State Life Ins. Co., I24 Okla. I55, 254 Pac. 7 (r927); Kukuska v. Home Mut. Hail-Tornado Ins. Co., 204 Wis. I66, 235 N.W. 403 (I93 I). Cf. also Wallace v. Hartford Fire Ins. Co., $3 x$ Idaho 48x, $x_{74}$ Pac. roog (Igr8); Lewis v. Brotherhood of Locomotive Firemen and Enginemen, 220 Ala. 270, I24 So. 889 (I929).

74 Columbian Nat. Life Ins. Co. v. Lemmons, 96 Okla. 228, 222 Pac. 255 (1923).

${ }^{75}$ Kukuska v. Home Mut. Hail-Tornado Ins. Co., 204 Wis. I66, 235 N.W. 403 (I93I).

${ }^{76}$ Cf. Trask v. German Ins. Co., 53 Mo. App. 625 (1893).

77 r Williston, Contracts, 83 ( $\mathrm{Ig} 20)$.

${ }^{8}$ Lombard v. Rahilly, I27 Minn. 449, I49 N.W. 950 (rgr4).

79 "Before a court sustains an action brought on the implied contract of the insurance company, it must answer these questions. Is the implication a reasonable deduction from all the circumstances and relations of the parties? And did the insurance company actually intend to promise that it would act upon the application within a reasonable time?" Parkhill, Effect of Delay in Acting upon an Application for Insurance, 7 Fla. Bar Assn. J. 219, 223 (r934).

80 "The suggestion that the insurer or the agent promises to act promptly ignores actuality. No such agreement is made expressly, nor can the intention to make one be implied. If a court should hold that a contract to decide expeditiously on the proposal did exist, it is believed that, within a short time, all insurance companies doing business in that jurisdiction would incorporate in their applications stipulations expressly negativing any such promise." Funk, The Duty of an Insurer to Act Promptly on Applications, 75 Univ. Pa. L. Rev. 204, 224 (1927).

8x See notes 7 and 8, supra and text. 
But if agreement is to be implied, it requires consideration. This has been found ${ }^{82}$ in the making of the application at the agent's solicitation. This amounts to saying that an offer to contract is consideration for an implied promise to act upon the offer-a proposition which is its own refutation. Nor does payment of an advance premium to the agent, relied upon in some cases, ${ }^{83}$ furnish the solution. The ownership of the money paid does not pass to the company until it accepts the offer; in the meantime it is deposited with the agent for a special purpose, pending a decision on the offer which it accompanies. ${ }^{84}$ The company in effect is given an option to accept the application and the money; and a deposit in connection with an option, to be returned if it is not taken up, is not consideration. ${ }^{85}$

"Quasi-contract" is equally a false hope. The term is used properly in cases where the plaintiff is reimbursed, or restored to his former status, to avoid unjust enrichment of the defendant. ${ }^{86}$ The company has not been enriched, since it holds the payment made merely in trust; and restoration of the applicant to his former status would involve at most a return of the premium. If "quasi-contract" is used, as the Wisconsin court apparently employs it, ${ }^{87}$ in the sense of a consensual understanding which is not a contract, it adds nothing to what has gone before.

The weakness of all theories based on contract has induced a number of courts, following the leading case of Duffie v. Bankers' Life Assn., ${ }^{88}$ to seek to evolve some basis of liability in tort. The company's dealings with the application are a departure from a reasonable standard of care. Pro-

82 Columbian Nat. Life Ins. Co. v. Lemmons, 96 Okla. 228, 222 Pac. 255 (r923).

$8_{3}$ Columbian Nat. Life Ins. Co. v. Lemmons, 96 Okla. 228, 222 Pac. 255 (r923); De Ford v. New York Life Ins. Co., 75 Colo. 146,224 Pac. ro49 (r924); Kukuska v. Home Mut. HailTornado Ins. Co., 204 Wis. I66, 235 N.W. 403 (I93 I). Cf. Metropolitan Life Ins. Co. v. Brady, 95 Ind. App. 564, I74 N.E. 99 (1932); Dunne v. Western Nat. Iife Ins. Co., 35 Wyo. 59, 246 Pac. 246 (I926).

$8_{4}$ "The money was paid upon a definite understanding in which the parties joined; it was to be held by the insurer pending its decision whether to issue the policy or not; if it decided to issue the policy the money was to be applied toward the first premium; but if it declined the application the money was to be repaid to the applicant. The money so paid could not become the property of the insurer until the policy was issued. The insurer held it in a fiduciary capacity, somewhat analogous to that in which a bank holds a special deposit." Swentusky v. Prudential Ins. Co., II6 Conn. 526, x65 Atl. 686 (1933).

${ }_{85}$ Cf. Friendly v. Elwert, 57 Or. 599, II2 Pac. 1085 (I9II).

${ }^{86}$ I Williston, Contracts, $\$ 4$ (I920); Miller v. Schloss, 2I8 N.Y. 400, II3 N.E. 337 (I9r6).

${ }_{8}$ Kukuska v. Home Mut. Hail-Tornado Ins. Co., 204 Wis. I66, 235 N.W. 403 (I93I).

${ }^{88}$ Duffie v. Bankers' Life Assn., I60 Iowa I9, I39 N.W. I087 (I9I3), 46 L.R.A. (N.S.) 25. 
vided that a duty to the applicant to use such care can be found, the company may be liable for its negligence. Much ingenuity has been devoted to the discovery of such a duty.

\section{DUTY BASED ON FRANCEISE FROM STATE}

The Duffie case first suggested ${ }^{89}$ that an insurance company, by doing business under a franchise from the state, had assumed a duty toward the public which required prompt action upon all applications submitted. Later decision $\mathrm{s}^{90}$ have followed this lead, and have advanced the franchise as one reason for tort liability.

The objection here is that there is nothing about a franchise, in itself, to impose any such duty. All corporations have franchises, and it does not appear that the obligations of the insurer would be altered if an individual were doing business. ${ }^{9 x}$ An insurance company is not a public utility, and the suggestion ${ }^{92}$ that it is required to accept all suitable applications never has been adopted by any court. The franchise merely gives the corporate insurer the right to transact business as an individual might, ${ }^{93}$

89 "This view overlooks the fact that the defendant holds and is acting under a franchise from the state. The legislative policy, in granting this, proceeds upon the theory that chartering such association is in the interest of the public to the end that indemnity on specific contingencies shall be provided those who are eligible and desire it and for their protection the state regulates, inspects, and supervises their business. Having solicited applications for insurance, and having so obtained them and received payment of the fees or premiums exacted, they are bound either to furnish the indemnity the state has authorized them to furnish or decline so to do within such reasonable time as will enable them to act intelligently and advisedly thereon or suffer the consequences flowing from their neglect to do so." Duffie v. Bankers' Life Assn., I60 Iowa I9, I39 N.W. I087 (I9r3), 46 L.R.A. (N.S.) 25.

90 De Ford v. New York Life Ins. Co., 75 Colo. 146, 224 Pac. 1049 (1924); Wilken v. Capital Fire Ins. Co., 99 Neb. 828, 157 N.W. I02I (rgI6); Security Ins. Co. v. Cameron, 85 Okla. I7 1 , 205 Pac. I5I (I922), 27 A.L.R. 444; Columbian Nat. Life Ins. Co. v. Lemmons, 96 Okla. 228, 222 Pac. 255 (1924); Stark v. Pioneer Cas. Co., 34 P. (2d) 73I (Cal. App. 1934); see Strand v. Bankers' Life Ins. Co., II5 Neb. 357, 213 N.W. 349 (I927); Royal Neighbors of America v. Fortenberry, $21_{4}$ Ala. 387 , 107 So. 836 (1926).

9x "Admitting all this, it is difficult to see the connection between the fact that the insurer enjoys a corporate franchise and its duty to act in a particular case. If the insurer were a person instead of a corporation, the duty to act would be the same under the same circumstances. In cases like this, the duty springs from the consensual acts of the parties and the surrounding circumstances rather than any specific provision of law applicable to the holder of the franchise as such." Kukuska v. Home Mut. Hail-Tornado Ins. Co., 204 Wis. $x 66,235$ N.W. 403 (r93I).

${ }_{9 z}$ See Patterson, The Delivery of a Life Insurance Policy, 33 Harv. L. Rev. I89, 2 I6 (rgIg).

93 "Every corporation has a franchise from the state, but it never has been thought that that fact changes as to corporations the elementary rule of the law of contracts and requires that corporations shall accept or reject offers to enter into contracts within a reasonable time, whereas individuals are not similarly restricted. The franchise but gives to a corporation the right to transact business as an individual might, and subject to the same rules which govern individuals." Munger v. Equitable Life Assur. Soc., 2 F. Supp. 914, 917 (D.C. Mo. 1933). 
and should impose no more duty to act without delay upon applications than would be required of a bank receiving a request for a loan. ${ }^{94}$

\section{BUSINESS AFFECTED WITH A PUBLIC INTEREST}

Associated with the concept of a duty imposed by the franchise is the contention, also advanced in the Duffie case, and repeated in later decisions, ${ }^{95}$ that insurance is a business so affected with a public interest that the company is under a public obligation to act promptly. The public interest is beyond dispute. There is no doubt that it will sustain the constitutionality of legislation regulating the conduct of the business. ${ }^{96}$ A statute which requires the company to act upon applications within a reasonable time would be constitutional. ${ }^{97}$ But such regulation is based upon the police power, the exercise of which is exclusively for the legislature, and not for the courts; and the courts cannot impose a duty upon insurers because the legislature might do so. ${ }^{88}$ The fact that the legislature has passed no such statute indicates, if anything, an intent that no such obligation shall be imposed. ${ }^{99}$ Banking is affected with a public in-

94 "The fact that the insurance companies are granted a franchise to do business in this state does not and should not impose upon them the duty to consider promptly all who offer to them the risk of insuring their lives, no more than would be required of a bank to lend money promptly to all who should make application and suffer loss while the bank was negligent in determining whether or not it would accept the offer and enter into a contract." Savage v. Prudential Life Ins. Co., 154 Miss. 89, I2I So. 487 (1929). See also Swentusky v. Prudential Ins. Co., II6 Conn. 526, I65 Atl. 686 (I933); Miller v. Illinois Life Ins. Co., 255 Tll. App. 586 (1930); American Life Ins. Co. v. Nabors (Tex. Comm. App. 1934) 76 S.W. (2d) 497.

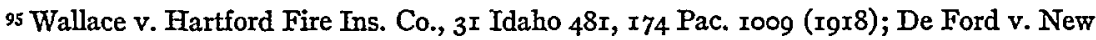
York Life Ins. Co., 75 Colo. I46, 224 Pac. ro49 (I924); Wilken v. Capital Fire Ins. Co., 99 Neb. 828, I57 N.W. I02I (I9I6); Fox v. Volunteer State Life Ins. Co., I85 N.C. I2I, II6 S.E. 266 (I923); Security Ins. Co. v. Cameron, 85 Okla. I7I, 205 Pac. I5I (I922), 27 A.L.R. 444; Columbian Nat. Life Ins. Co. v. Lemmons, 96 Okla. 228, 222 Pac. 255 (I924); Brown v. Missouri State Life Ins. Co., I24 Okla. 155, 254 Pac. 7 (I927); Dyer v. Missouri State Life Ins. Co., I32 Wash. 378, 232 Pac. 346 (I925).

${ }_{96}^{6}$ Northwestern Nat. Life Ins. Co. v. Riggs, 203 U.S. 243 (rg06), 7 Ann. Cas. 1104 (misrepresentation); Whitfield v. Aetna Life Ins. Co., 205 U.S. 489 (rgo7) (suicide defense); German Alliance Ins. Co. v. Lewis, 233 U.S. 389 (I9I4), L.R.A. I9I5C II89 (rates); Hardware Dealers Mut. Fire Ins. Co. v, Glidden Co., 284 U.S. I5I (I93I) (compulsory arbitration); O'Gorman \& Young v. Hartford Fire Ins. Co., 282 U.S. $25 x$ (r93 I) (commissions of agents).

${ }_{97}$ National Union Fire Ins. Co. v. Wanberg, 260 U.S. 7 I (I922).

98 "State regulation of insurance companies has its basis in the police power and by no means in the public interest with which the insurance business is affected. The fact of public interest is not the source of that power, it but affects the locus of the boundary line limiting its exercise. And the police power is exclusively to be exercised by the Legislature, never by the judicial branch of government. The courts cannot impose a duty on insurance companies by virtue of a power which the courts do not possess and cannot exercise." Munger v. Equitable Life Assur. Soc., 2 F. Supp. 9I4, 9 I8 (D.C. Mo. I933).

99 "These very regulations, however, seem to the court to negative the claim of the plaintiffs in this suit. By reason of the fact that they are quasi public corporations, the Legislature 
terest, but it never has been suggested that a bank may be required to act promptly on a requested loan; $;^{\text {xo0 }}$ employment is a matter of the greatest public interest, yet there is no duty to act without delay on an application for a job. ${ }^{\text {ror }}$ There is nothing in the business of insurance to call for any different rule. ${ }^{\text {ro2 }}$

\section{DUTY OF THE AGENT TO FORWARD THE APPLICATION}

The agent who takes the application does so in the course of his employment. If he owes any duty to the applicant to exercise due care in dealing with it, and fails to do so - as by failure to forward it promptlyhis negligence is chargeable to the company. ${ }^{\text {I03 }}$ The difficulty lies in finding any such duty. Early cases assumed it; ${ }^{\text {I04 }}$ later ones have accepted

has prescribed in certain respects what their duties are, particularly as regards the form of contract, but nowhere does the Legislature charge them with as broad a duty as the plaintiffs herein claim. Except with respect to such changes as have been made by legislative enactment, it does not appear that in our law there is any greater duty imposed upon the parties entering into an insurance contract than is required in other contracts." Weatherby v. Aetna Ins. Co., II N.J.M. 435, I67 Atl. 877 (r933).

${ }^{200}$ Savage v. Prudential Life Ins. Co., I54 Miss. 89 , x21 So. 487 (1929); Miller v. Mllinois Life Ins. Co., 355 Tll. App. 586 (1930); 32 Mich. L. Rev. 395 (I934).

sot "No reason is apparent why an insurance contract should be regarded as of any more interest to the public than a contract of employment. It is of as much importance to the public that a person and his dependents have support during his lifetime (by wages or salary) as that his beneficiaries have a competency (through insurance) after his death. Yet it has never been held that delay in passing upon an application for employment affected the public interest to the extent that it made the employer liable for all damages arising from such delay." Thornton v. National Council Junior Order United American Mechanics, Iro W.Va. 412, 158 S.E. 507 (I93r). See also Raysor v. Berkeley Co. Ry. \& Lumber Co., 26 S.C. 6ro, 2 S.E. IIg (I887); Hurley v. Eddingfield, I56 Ind. 4I6, 59 N.E. Io58 (Igor) (physician).

${ }^{102}$ Swentusky v. Prudential Ins. Co., Ir6 Conn. 526, I65 Atl. 686 (r933); Schliep v. Commercial Cas. Ins. Co., I9r Minn. 479, 254 N.W. 6 I8 (I934); American Life Ins. Co. v. Nabors, 76 S.W. (2d) 497 (Tex. Comm. App. 1934).

${ }_{103}$ "If the agent only be considered, it is clear enough that he would be liable if his negligent retention of the application prevented its timely acceptance. Since he was merely the arm of the defendant, the obligation resting upon him was the obligation of the defendant. Therefore the duty of the defendant to secure prompt transmission of the application from the solicitor's field to the central office is quite apparent." Boyer v. State Farmers' Mut. Hail Ins. Co., 86 Kan. 442, I21 Pac. 329 (I912), 40 I.R.A. (N.S.) I64, Ann. Cas. I9I5A 67x.

To the contrary is Four States Grocer Co. v. Wickendon, 2I7 S.W. IIo3 (Tex. Civ. App. I9I9), holding that where a salesman took an order for three bales of duck and failed to forward it, his negligence was not chargeable to his employer, because "the employer was in no sense a party to the transaction of taking the order." The case is criticized in 29 Yale L. J. 673 (1920).

${ }^{104}$ Carter v. Manhattan Life Ins. Co., Ir Hawaii 69 (I897); Boyer v. State Farmers' Mut. Hail Ins. Co., 86 Kan. 442, I2I Pac. 329 (19I2), 40 L.R.A. (N.S.) I64, Ann. Cas. Igr5A 671. 
the assumption, ${ }^{\text {105 }}$ and the basis for it is clearly stated nowhere. It has been said that:

there was sufficient danger to the plaintiff to be apprehended from delay in closing the transaction that a reasonably prudent business man, guided by the considerations which ordinarily regulate conduct, would have acted with diligence. ${ }^{\text {.06 }}$

But, as Mr. Funk has pointed out, ${ }^{\mathrm{r} 7}$ this merely begs the question; regardless of the apprehension of danger to another, even a reasonably prudent business man is not required to act with diligence, unless he is under a legal duty to do so. It has been said ${ }^{108}$ that "equity considers that as done which ought to have been done"; but this assumes that the company was under some obligation to take action, which is the thing to be proved, ${ }^{\text {rog }}$ and is at best a poor reason for affording relief in a tort action at law. There has been mention ${ }^{\text {rro }}$ of an "implied agreement" based on the agent's receipt of the application and the premium; but it should be evident that they have been received by the agent as the representative of the company, and that he has assumed no obligations which the company would not itself assume if the transaction had been direct. ${ }^{\text {Irx }}$

\section{THE AGENT AS TRUSTEE}

In a Nebraska case liability has been rested upon the principle that the agent, when he receives payment of the premium, becomes a trustee of the money, and "negligent or inexcusable delay on the part of a trustee is a wrong, if it deprives the beneficiary of the use of a trust fund which has served its purpose as such."rr2 Assuming that the agent has become a trustee, and that one of the agreed terms of the trust is that the money

ros Wallace v. Hartford Fire Ins. Co., 3 I Idaho 48I, I74 Pac. I009 (xgI8); Wilken v. Capital Fire Ins. Co., 99 Neb. 828, I57 N.W. IO2I (rg16); Security Ins. Co. v. Cameron, 85 Okla. I7I, 205 Pac. I5I (I922), 27 A.L.R. 444; Dyer v, Missouri State Life Ins. Co., I32 Wash. 378, 232 Pac. 346 (I925); Lewis v. Brotherhood of Locomotive Firemen and Enginemen, 220 Ala. 270, I24 So. 889 (I929); $f f$. Fox v. Volunteer State Life Ins. Co., x85 N.C. I21, xI6 S.E. 266 (I923).

${ }^{106}$ Boyer v. State Farmers' Mut. Hail Ins. Co., 86 Kan. 442, I2I Pac. 329 (I9I2), 40 L.R.A. (N.S.) 164 , Ann. Cas. I915A 67 I.

${ }^{\text {so }}$ Funk, The Duty of an Insurer to Act Promptly on Applications, 75 Univ. Pa. L. Rev. 207, 214 (r927).

${ }^{208}$ Carter v. Manhattan Life Ins. Co., Ir Hawaii 69 (I897); Stark v. Pioneer Cas. Co., 34 P. (2d) 73 I (Cal. App. 1934).

${ }^{109}$ See Munger v. Equitable Life Assur. Soc., 2 F. Supp. 9r4, 9 r 7 (D.C. Mo. I933).

zso Columbian Nat. Life Ins. Co. v. Lemmons, 95 Okla. 228, 222 Pac. 255 (x923); De Ford v. New York State Life Ins. Co., 75 Colo. I46, 224 Pac. I049 (I924); Dyer v. Missouri State Life Ins. Co., ${ }^{32}$ Wash. 378,232 Pac. 346 (r925). Cf. Wallace v. Hartford Fire Ins. Co., $3^{I}$ Idaho 48r, I74 Pac. I009 (IgI8).

Ix See notes 73 to 85 supra inclusive, and text.

II2 Strand v. Bankers' Life Ins. Co., II5 Neb. 357, 213 N.W. 349 (I927). Cf. also Fox v. Volunteer State Life Ins. Co., I85 N.C. I2I, II6 S.E. 266 (I923), where the agent was said to be a "trustee" of the policy after it was issued, and the company held liable for his delay in delivery. 
will not be retained after a lapse of a reasonable time, if the application is not accepted, then the trust requires only that the payment be returned to the applicant; and its enforcement, which properly would be in equity rather than in a tort action at law, would appear to be limited to the restoration of the trust fund. It does not follow that there is any agreement to act on the application, or any responsibility for loss resulting from failure to do so. ${ }^{\mathrm{II} 3}$ The agent can be held to no greater duty than would rest upon the company if direct payment had been made.

\section{AFFIRMATIVE CONDUCT}

It has been suggested ${ }^{\mathrm{rr}} 4$ that the duty of the agent to use care in dealing with the application may be based on the principle, familiar in negligence cases, ${ }^{\mathrm{Ir} 5}$ that one who enters upon an affirmative undertaking, to perform a gratuitous service for another, is required to exercise reasonable care in performing it, to avoid injury to the beneficiary of the undertaking. The ancient distinction between nonfeasance and misfeasance finds support in cases involving brokers and others who undertake to procure insurance. If there is nothing more than a voluntary promise, there is no obligation to carry it out;:;16 but once the defendant has entered upon the undertaking by some affirmative act, he may be liable for negligence if he abandons it, or fails to use proper care. ${ }^{\text {II }}$ Insurance agents who take applications, particularly where they receive premiums, may be said to have entered definitely upon a course of affirmative conduct, and be liable for misfeasance if they unreasonably delay.

${ }_{13}$ "The declaration of the Supreme Court of Nebraska that the basis of the asserted duty, when an advance premium has been paid, is the obligation incumbent on a trustee faithfully to discharge his trust, assumes a trust agreement including an agreement, expressed or implied, that what has been paid will not be held indefinitely if the application is not accepted. If this be granted, the full duty of the trustee is to return the premium advanced. The further assumption that the trustee has agreed to act one way or the other on the application and has therefore a contractual duty to act begs the whole question as to whether there is such a duty. Moreover, the enforcement of a trust, and the awarding of damages incidental to its violation, is for equity, not for a court of law." Munger v. Equitable Life Assur. Soc., 2 F. Supp. 9r4, 9I7 (D.C. Mo. 1933).

${ }^{21} 4$ Budge, C. J., concurring specially in Wallace v. Hartford Fire Ins. Co., 3r Idaho 48r, 174 Pac. roog (rgr8); 3 Minn. L. Rev. 53 (Igr8).

rrs Harper, Treatise on the Law of Torts, $\$ 8 \mathrm{I}$, pp. 200-206 (1933); Bohlen, Studies in the Law of Torts, p. 80 (1926).

${ }^{216}$ Thorne v. Deas, 4 Johns. (N.Y.) 84 (I809); Comfort v. McCorkle, I49 Misc. 826, 268 N.Y.S. I92 (1933).

${ }^{117}$ Siegel v. Spear \& Co., 245 N.Y. 479, I38 N.E. 4I4 (I925), 26 A.L.R. I205; Barile v. Wright, 256 N.Y. I, 775 N.E. 35I (193I); Condon v. Exton-Hall Brokerage \& Vessel Co., 80 Misc. 369 , 142 N.Y.S. 548 (rgr3); Backus v. Ames, 79 Minn. 145, 8I N.W. 766 (rg00); Criswell v. Riley, 5 Ind. App. 496, 30 N.E. Iror, 32 N.E. 814 (I892); Rezac v. Zima, 96 Kan. 752, I53 Pac. 500 (Igr5), Ann. Cas. I9I8B I035; Evan I. Reed Mfg. Co. v. Wurts, I87 Ill. App. 378 (19r4). 
This argument is entitled to respect. The objection to it would appear to be, that in the broker cases the one who undertakes to procure insurance is assuming a voluntary agency for the plaintiff, and so owes him a duty to protect him by proper care. At least he is not a hostile party, or dealing at arm's length. But the insurance agent here is not the agent of the applicant, or primarily responsible to him. He is the agent of the company, and his undertaking is that of the company.

Whether or not he owes a duty to act promptly on the application depends on just the same considerations as whether the company owes any duty to act on the proposal within a reasonable time. ${ }^{\text {.18 }}$

It never has been held that the rule as to affirmative undertakings extends to the offeree who is dilatory in dealing with an offer, ${ }^{\mathrm{Ir} 9}$ and there would appear to be no reason why it should extend to his agents.

Even assuming that it can be established, upon one or another of the foregoing theories, that the insurance company has violated a duty to the applicant, other difficulties remain. It is not at all clear that the defendant's negligence has been the proximate cause of any injury to the plaintiff. It would be absurd to say that the company has caused the actual loss which has occurred. At most it has caused the applicant to remain uninsured. Notwithstanding some occasional confusion in the cases, ${ }^{\text {I20 }}$ it seems clear that the insurance of which he has been deprived is not that which might have been written by the defendant company, since he had no right to assume that his application would be accepted. If anything, he has lost the opportunity, or expectancy, of obtaining insurance from another company. ${ }^{12 x}$ Granted that this is a legal right, or interest, what is its value? Normally very little, since the premium he must pay for insurance will equal its worth. The especial importance which the expectancy has for this plaintiff arises from the fact that he has suffered a loss; but for this the defendant is in no way responsible. Should such especial value be an element of damages? Suppose that A is negotiating with $B$ for the sale of A's horse, and C wrongfully persuades $B$ not to enter into the contract. Thereafter A's horse dies. C has interfered with an expectancy-should he pay for the loss of the horse? And is it even clear that the insurance company has deprived the applicant

${ }^{18} 8$ Funk, The Duty of an Insurer to Act Promptly on Applications, 75 Univ. Pa. L. Rev. 207, 2I9 (I927).

Ir9 See Swentusky v. Prudential Ins. Co., II6 Conn. 526, 533, r65 Atl. 686, 688 (r933).


Fox v. Volunteer State Life Ins. Co., I85 N.C. r21, Ir6 S.E. 266 (r923).

${ }^{22}$ Duffie v. Bankers' Life Assn., I60 Iowa I9, I39 N.W. 1087 (I9I3), 46 L.R.A. (N.S.) 25; Strand v. Bankers' Life Ins. Co., II 5 Neb. 357, 213 N.W. 349 (1927); Wallace v. Metropolitan Life Ins. Co., 212 Wis. 346, 248 N.W. 435 (1933); Behnke v. Standard Acc. Ins. Co., 4I F. (2d) 696 (C.C.A. 7 th 1930 ). 
of his expectancy? He might obtain other insurance even yet, if no loss had occurred, and defendant has not caused the loss. ${ }^{122}$

But even if we are to regard the defendant's conduct as creating the risk of "loss without insurance," it would seem that the applicant should be required to exercise reasonable care for his own protection. The company has delayed an unreasonable length of time. The applicant has an equal interest in the fate of the application. Unless he has at least made inquiry of the agent, and received assurances that the matter would be taken care of, can it be said that his failure to withdraw his offer and seek other insurance is caused by the defendant's delay, or by anything but his own willingness to afford additional time for consideration? ${ }^{123}$ It should at least appear, not only that he was eligible for insurance, ${ }^{\mathrm{I2}}$ but that after the lapse of a reasonable time he was in fact induced by the company's conduct to forego a possible attempt to obtain it elsewhere..$^{125}$ There is an astonishing lack of any such evidence in the cases imposing liability.

Finally, in the case of life insurance, there is the problem of the party who is to bring the action. The applicant, to whom any duty primarily was owing, is dead. The beneficiary, who is the one party with any real expectancy of getting the money, is almost unanimously denied recovery, ${ }^{\text {I26 }}$ upon the ground that the company has no relations with him, and

${ }_{22}$ "Certainly then his ability to procure insurance has been terminated, but is that inability to procure insurance proximately caused by the inaction of the company so that that could be considered in determining the measure of A's damages by such inaction? I think A's inability then to procure insurance is proximately caused by his death, and not by the inaction of the company on his application for insurance. The damages, if any, which he had before he met with accident certainly cannot all at once be multiplied a hundred fold by an event for which the company is not responsible and having no causal connection with its inaction on his application for insurance." Munger v. Equitable Life Assur. Soc., 2 F. Supp. 9r4, 920 (D.C. Mo. I933).

${ }_{223}$ See Insurance Co. v. Johnson, 23 Pa. 72 (I854); Alabama Gold Life Ins. Co. v. Mayes, 6r Ala. I63 (1878); Royal Ins. Co. v. Beatty, I I9 Pa. St. 6, r2 Atl. 607 (I888); Winchell v. Iowa State Ins. Co., Io3 Iowa $189,7^{2}$ N.W. $5^{\circ} 3$ ( 899 ); Savage v. Prudential Life Ins. Co., r54 Miss. 89, I21 So. 487 (rg29); Munger v. Equitable Life Assur. Soc., 2 F. Supp. gr4 (D.C. Mo. I933). Cf. Lamb v. Mechanics' Ins. Co., I22 Kan. 352, 252 Pac. 213 (I927); Moon v. Central States Fire Ins. Co., I38 Kan. 83, 23 P. (2d) 444 (r933).

124 There is general agreement that if the applicant was not an acceptable risk, there is no liability upon the company. Northwestern Mut. Life Ins. Co. v. Neafus, $\mathrm{r}_{45} \mathrm{Ky} \cdot 5^{6} 3$, I40 S.W. I026 (rgrI); Dorman v. Connecticut Fire Ins. Co., 4I Okla. 509, I39 Pac. 262 (IgI4); Gonsoulin v. Equitable Life Assur. Soc., $x_{52}$ La. 865, 94 So. 424 (I922); Moon v. Central States Fire Ins. Co., I38 Kan. 83, 23 P. (2d) 444 (I933); Wallace v. Metropolitan Life Ins. Co., 2I2 Wis. 346, 248 N.W. 435 (1933); Weaver v. West Coast Life Ins. Co., 42 P. (2d) 729 (Mont. I935); see Behnke v. Standard Acc. Ins. Co., 4I F. (2d) 696 (C.C.A. 7th I930).

${ }_{225}$ Wallace v. Metropolitan Life Ins. Co., 2I2 Wis. 346, 248 N.W. 435 (I933); see Behnke v. Standard Acc. Ins. Co., 4 r F. (2d) 696 (C.C.A. 7th I930).

${ }_{226}$ Royal Neighbors of America v. Fortenberry, 2r4 Ala. 387, ro7 So. 846 (r926); Veser v. Guardian Life Ins. Co., 44 Ohio App. 293, I85 N.E. $5^{65}$ (1932); Stray v. Western States Life 
its duty did not extend to him. ${ }^{\mathrm{x} 7}$ If the administrator of the decedent's estate is to bring the action, it must be because some right of the decedent has survived, for obviously the cause of action has accrued before death, and the estate has suffered no new injury after death. If the action is in tort, ${ }^{128}$ the problem is to find some statute which will permit it to survive. ${ }^{\mathrm{x} 9}$ In any event, it would seem that the estate should recover nothing more than nominal damages, since the prospective insurance money would not be payable to the estate, and the defendant has not caused the actual loss. ${ }^{\text {130 }}$

The infinite variety of these legal theories, not yet withered by age or made stale by custom, suggests that there is no real logical basis for liability, and that the recent cases which have denied it ${ }^{\mathrm{xI}}$ are those which ultimately will be followed. ${ }^{132}$ If there is "a great need for the courts to

Ins. Co., $x 63$ Wash. 329, 300 Pac. ro46 (I93I); Forck v. Prudential Ins. Co., 66 S.W. (2d) 983 (Mo. App. 1933). See also Duffie v. Bankers' Life Assn., r60 Iowa rg, r39 N.W. ro87 (1913), 46 L.R.A. (N.S.) 25; De Ford v. New York Life Ins. Co., 75 Colo. I46, 224 Pac. I049 (1924). Cf. Miller v. Illinois Life Ins. Co., 255 Ill. App. 586 (1930).

${ }_{227}$ Both Funk, The Duty of an Insurer to Act Promptly on Applications, 75 Univ. Pa. $\mathrm{L}$. Rev. 207, 225 (1927), and Parkhill, Effect of Delay in Acting upon an Application for Insurance, 7 Fla. Bar Assn. J. 219, 224 (I934), argue in favor of a recovery by the beneficiary, upon the ground that the "expectancy" of insurance protection is really in him, and that as a third party beneficiary of the prospective contract, he is entitled to relief. There is no support for this conclusion except a dictum in Thornton v. National Council Junior Order United American Mechanics, Iro W.Va. 412, r58 S.E. 507 (I93I), and an overruled decision in Texas. American Life Ins. Co. v. Nabors, 48 S.W. (2d) 459 (Tex. Civ. App. 1932), reversed in 76 S.W. (2d) 497 (Tex. Comm. App. I934).

${ }^{228}$ Hence the attempt to base the tort action upon a duty arising out of an implied contract. Columbian Nat. Life Ins. Co. v. Lemmons, 96 Okla. 228, 222 Pac. 255 (I923); Dyer v. Missouri State Life Ins. Co., I32 Wash. 378, 232 Pac. 346 (I925).

${ }^{129}$ The Colorado statute quite clearly provides for survival. De Ford v. New York Life Ins. Co., 75 Colo. I46, 224 Pac. I049 (I924). Also apparently that of Iowa. Iowa, Code (I924), § ro957; Duffie v. Bankers' Life Assn., I60 Iowa I9, I93 N.W. I087 (IgI3), 46 L.R.A. (N.S.) 25. The statutes of Oklahoma and Washington apparently contemplate the survival only of actions based on contract. Columbian Nat. Life Ins. Co. v. Lemmons, 96 Okla. 228, 222 Pac. 255 (I923); Dyer v. Missouri State Life Ins. Co., I32 Wash. 378, 232 Pac. $346^{\circ}$ (r925). The Missouri statute has been construed not to permit survival. Munger v. Equitable Life Assur. Soc., 2 F. Supp. $9 I_{4}$ (D.C. Mo. I933). In general, actions for torts other than personal torts may survive, 3 Schouler, Law of Wills, Executors and Administrators $\$ 2$ 2188, p. 2080 (6th ed. I923); but there is no common law precedent for the survival of such an action as this, and the matter would seem to be controlled entirely by the wording of the statute.

${ }^{130}$ Thornton v. National Council Junior Order United American Mechanics, I Io W.Va. 4 I2, I58 S.E. 507 (I93I); Funk, The Duty of an Insurer to Act Promptly on Applications, 75 Univ. Pa. L. Rev. 207 (I927). Cf. Bradley v. Federal Life Ins. Co., 295 Ill. 38I, I29 N.E. I7I (I920).

${ }^{x_{3 x}}$ See note 4 , supra.

${ }^{{ }^{32}}$ The prediction of Funk, The Duty of an Insurer to Act Promptly on Applications, 75 Univ. Pa. L. Rev. 207, 226 (r927), that "if a survey be made in years hence, it will be found that the insurer, in the majority of instances, will have been required to answer in damages for its negligent delay," does not appear to have been borne out, at least in the later cases. 
recognize the position of guardianship occupied by the insurer in society and to endow the insurer with a responsibility for efficient action greater than is required of the corner grocer," ${ }^{\text {'33 }}$ it should at least be done outright by judicial fiat, instead of warping established concepts to produce a "novel, interesting and rather surprising" 34 result. It would perhaps be better still to leave such legislation where it properly belongs, ${ }^{\mathrm{x} 35}$ and to solve the problem by the passage of statutes similar in character to that of North Dakota. ${ }^{x^{3}}$

If such a statute is to be proposed, it would seem that it should begin by fixing a definite period within which the insurance company shall be required to communicate its acceptance or rejection of the application. A provision for a "reasonable time" ${ }_{x_{3} 7}$ is a mere invitation to litigation. The time might vary with the type of insurance: hail insurance might very well require no more than twenty-four hours, ${ }_{2}{ }^{138}$ while fire insurance, where investigation may be necessary, might require at least a week, while life insurance might call for as much as a month. ${ }^{{ }^{3} 9}$ Since virtually all of the decisions imposing liability have involved a prepayment of the premium, ${ }^{\text {I40 }}$ the statute might perhaps be limited to cases where some advance pay-

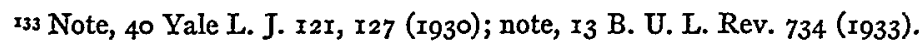

${ }_{334}$ Vance, Handbook of the Law of Insurance $\S 64$, p. rgo (2d ed. 1930 ).

${ }^{235}$ "It is apparent that if liability is here to be imposed in an action ex delicto, this court will be compelled to engage in judicial legislation. If and when it is desired to impose upon insurers additional burdens or requirements, the same should come through the legislative department of the government, and not by virtue of judge-made law." Olson, J., in Schliep v. Commercial Cas. Ins. Co., I9r Minn. 479, 488, 254 N.W. 618 (1934).

"Now, when the mills, called Parliaments and Congresses and Legislatures, grind out new laws unceasingly to meet the real or imagined demands of changed and changing times, courts may well restrain themselves to the discharge of their true function, the interpretation of the law that is, not the making of the law as it should be. As for myself, proceeding super antiquas vias, I shall not say that because there ought to be a law requiring an insurance company to act within a reasonable time on an application for insurance, therefore that is the law." Otis, J., in Munger v. Equitable Life Assur. Soc., 2 F. Supp. 914, 9I7, 198 (D.C. Mo. 1933).

${ }^{3}{ }^{6}$ I N.D. Comp. L. (I 1913$)$, $\$ 4902$, held constitutional in Wanberg v. National Union Fire Ins. Co., 46 N.D. 369 , 179 N.W. 660 (1920); National Union Fire Ins. Co. v. Wanberg, 260 U.S. 7 I (I922). The statute requires all writers of hail insurance to act upon applications within twenty-four hours.

${ }_{337}$ Proposed in note, ro Wis. L. Rev. 289 ( 1935 ).

${ }_{{ }^{3} 8}$ The North Dakota statute allows twenty-four hours (see note ${ }_{13} 6$, supra). In Boyer v. State Farmers' Mut. Hail Ins. Co., 86 Kan. 442, I21 Pac. 329 (Igr2), 40 L.R.A. (N.S.) I64, Ann. Cas. 19r $5 \mathrm{~A} 67 \mathrm{r}$, a finding that a delay of three days in forwarding the application was unreasonable, was upheld.

${ }^{139}$ In Harp v. Grangers Mut. Fire Ins. Co., 49 Md. 307 ( 8878$)$; Evans v. International Life Ins. Co., I22 Kan. 264, 252 Pac. 266 (r927); Meyer v. Central States Life Ins. Co., ro3 Neb. $640,173$ N.W. 578 ( $19 \mathrm{gr})$; and Winn v. John Hancock Mut. Life Ins. Co., 216 Iowa 1249, $25^{\circ}$ N.W. 459 (1933), delays approaching a month were held to furnish no evidence of negligence.

x40 Metropolitan Life Ins. Co. v. Brady, 95 Ind. App. 564, 174 N.E. 99 (I932); Dunne v. Western Nat. Life Ins. Co., 35 Wyo. 59, 246 Pac. 246 (I926). 
ment has been made, upon the ground that there is little likelihood that the applicant will be misled by the belief that he is certain to receive protection, unless he has paid for it; but this may be debatable. ${ }^{\mathbf{1}}$ The liability of the insurer might properly be limited to losses occurring before the applicant has a reasonable opportunity to obtain other insurance, ${ }^{{ }_{4}{ }^{2}}$ or within a definite period after the expiration of the time for action. In the case of life insurance, the action should be vested in the beneficiary, ${ }^{\mathrm{I} 43}$ to avoid the possibility that the proceeds will go to satisfy creditors, or be distributed to other parties. ${ }^{\mathrm{I} 44}$

Such a statute would deprive insurance companies of the possibility, which seems now to be open to them, ${ }^{{ }^{145}}$ of inserting in the application an express provision that, if the offer is not accepted within a definite time, it shall be deemed to have been rejected..$^{{ }^{46}}$ At present, there seems to be no reason why such a provision should not protect the company against liability. ${ }^{147}$ In violation of a statute, it could of course have no effect. ${ }^{{ }^{148}}$

${ }_{24}$ See note, Io Wis. L. Rev. 289 (1935).

${ }^{142}$ Note, to Wis. L. Rev. 289 (1935). The proposed wording is: "Whenever any person shall be damaged, whether by reason of the company's unreasonable failure to accept or reject an application before a loss occurs, or whether by reason of such unreasonable delay the applicant has not had opportunity to amend his application or to insure elsewhere before such loss occurs, the company shall be liable as though the application had been accepted, but the policy not yet delivered."

${ }_{143}$ Note, ro Wis. L. Rev. 292 (1935). The proposed wording is: "In the case of life insurance, the right to recover under this section shall vest in the same person or persons as though the policy had been issued at the time of the applicant's death."

${ }^{244}$ In In re Coughlin's Estate, 53 N.D. I88, 205 N.W. I4 (r925), the proceeds were held exempt, under a statute providing that the "avails" of an insurance policy should not be subject to the debts of the deceased. It does not follow that the same result would be reached under a less liberal wording.

${ }^{{ }_{4} 5}$ See Jones, Tort or No Tort, 56 Chi. Leg. N. 366 (x924), 2 Proceedings Assn. of Life Ins. Counsel 389; Funk, The Duty of an Insurer to Act Promptly on Applications, 75 Univ. Pa. L. Rev. 207, 225 (I927).

${ }^{14^{6}}$ The clause proposed by Jones (see note 145, supra) is as follows: "The Company shall be entitled to ....... days from the date of this application within which to consider and act upon same; and if a policy has not been received by me, or if $I$ have not received notice of the approval or rejection of this application within that period, then this application will be deemed to have been declined by the Company."

${ }^{x 47}$ See Stilwell v. Covenant Mut. Life Ins. Co., 83 Mo. App. 215 ( 1900$)$. Cf. the provision in Stearns v. Merchants' Life \& Cas. Co., 38 N.D. 524,165 N.W. 568 ( $\left(99 \mathrm{r}_{7}\right)$, providing for the return of the premium paid within twenty days if the policy was not issued, which was held to give the Company an option to decline within twenty days.

Funk, The Duty of an Insurer to Act Promptly upon an Application, 75 Univ. Pa. L. Rev. 207,225 ( 1927 ), considers that such a clause would not protect the company against liability for loss occurring within the stated period, if it could be shown that the company could have acted earlier but failed to do so.

${ }_{{ }_{14}^{8}}^{8}$ Wanberg v. National Union Fire Ins. Co., 46 N.D. 369 , r79 N.W. 660 (ז920); National Union Fire Ins. Co. v. Wanberg, 260 U.S. 7 I (I922). 